\title{
The Face of Nature in Massureq Oral Tradition
}

\author{
Uniawati $^{1}$ \\ Student of Doctoral Program in Humanities, Faculty of Cultural Studies, Gadjah Mada \\ University $^{1}$ \\ \{uniawati81@ugm.ac.id ${ }^{1}$ \}
}

\begin{abstract}
This paper provides a discussion on the meaning of metaphors and symbols of nature which is expressed in massureq oral tradition Buginese. The main problems discussed are how to read meaning of the metaphors and symbols as representation face of nature expressed in massureq oral tradition? The reading aims to understand the meaning of metaphors and symbols that contain messages from nature. The data were obtained by recording the massureq procession in the maddoja bine ritual. The data is transcribed, translated, then analyzed with an emphasis on texts metaphors and symbols that represent nature. The perspective used in the analysis is Paul Ricoeur's Hermeneutics. The analysis showed that the face nature that is depicted through the massureq oral tradition is actualized through metaphors and symbols coherently and meaningful. The meaning presented represents the face of nature in an ideal construction that obeys the law of balance, conformity, and harmony.
\end{abstract}

Keywords: oral tradition; massureq, face of nature; meaning; Hermeneutics

\section{Introduction}

Most of oral tradition speaks about the face of nature. However, in Massureq oral tradition of agrarian Buginese, the face of nature is uniquely expressed. Its uniqueness can be traced in sureq literature of "Mêong Palo Karellaê" which narrates the story of Sangiangserri's long journey with his guardian cat named Mêong Palo Karellaê, which is often sung at night maddoja binê (staying up late to protect rice seeds)[1][2]. In that journey, the breath of nature is so strong that it blows local wisdom of nature in almost every event that takes place. The breath of nature is a reflection of relationship between human beings and environment as a mother.

Nature is a part of universe in which human lives interacts and express their thoughts through speech which later developed into oral traditions. Through their oral tradition, some ethnic groups share their stories on naturehas even been discussed seriously through several studies. For example, a study on the role of oral traditions in nature conservation in the Palue indigenous community[3]; the study of oral traditions in India as a medium of communication to convey messages of caring for nature[4]; study of environmental wisdom in the oral tradition of North Sumatra[5]; and studies of Buginess human environmental wisdom in the manuscript "Mêong Palo Karellaê" [2]. All of these studies talk about the relationship between 
nature and oral traditions, but they do not specifically look at how the face of nature is expressed through language.

The study of the massureq oral tradition also does not escape this problem.Therefore, it should be seen in different and new perspective. As a masterpiece of old generation, sureq texts actually has a distinctive way of that is expressed through literal language, metaphors, and symbols.

In Paul Ricoeur's Hermenetics, both metaphors and symbols are stepping stones in understanding the meaningof the text. Reading metaphors should not be done in word semantic level, but rather in sentence level to result in metaphoric statements. Metaphor reading helps provide initial comprehension of new reality construction in a discourse before stepping into reading symbols. However, meanings in symbols contradict with the metaphors since the reality in symbols turns down the linguistic, semantic and logical transcript[6]. Both ways are key to understanding the meaning of the face of nature expressed in sureq "Mêong Palo Karella $e^{\jmath \prime}$ texts that will be analyzed comprehensively in this paper. A related study was previously carried out by Rahman [2] on the environmental wisdom of the Buginese through the "Mêong Palo Karellaê text ". However, this study focuses more on the study of philology so that natural problems are addressed in a limited manner. This study aims to fill gaps that have not been touched by previous studies, especially regarding metaphors and symbols. Understanding of the meaning of metaphors and symbols in the "Mêong Palo Karellae" sureq can help put the ideal concept of nature in the mind of the Buginese.

\section{Methods}

This research is qualitative using Paul Ricoeur's Hermenetics approach. The data analyzed is "Mêong Palo Karellaê" sureq text with the focus on parts dominantly representing the face of nature. The data is acquired through the recording of massureq tradition on maddoja binê night in Mamminasae, Lamuru District, Bone Regency, South Sulawesi Province.।

Analyzing is done by identifyng dominant symbols and metaphors expressing the face of nature. The next step is reading metaphors and symbols by using Paul Ricoeurs' persepective in understanding the face of nature, expressed in "Mêong Palo Karellaê" sureq text.

\section{Result}

The face of nature expressed in "Mêong Palo Karellaê" sureq text is generally present in a form of metaphors and symbols which can be identified. These metaphors and symbols are unique as they use La Galigo, Bugis language that is pretty difficult to understand. Their diction is archaic words usedin daily life. Therefore, it is hard to understand.

Through careful reading using Paul Ricoeur's Hermenetics approach, some metaphors and symbols can be identified. Yet, there are only three metaphors and symbols whose meaning dominanty represents the face of nature and is eligible to be discussed here.

Table 1. Metaphors and Symbol

\begin{tabular}{llll}
\hline \multicolumn{1}{c}{ Metaphors } & & Symbol \\
\hline $\begin{array}{l}\text { natunai manaq langi } \\
\text { defamed by the ruler of sky' }\end{array}$ & & was & langi 'sky'
\end{tabular}




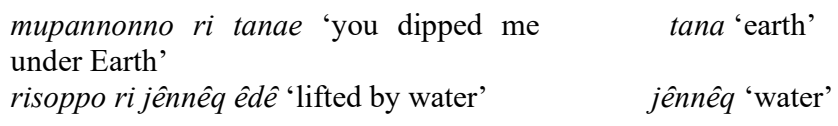

The table indicates that the concept nature dominating the landscape of Buginese's mind is reflected in three dimensions: langi 'sky', tana 'earth', and jênnêq 'water'. They represent the layers of nature to which they are interconnected and influenced. The meaning of balance, conformity and harmony is the face of nature expected to be present in the life of agrarian Buginese.

\section{Discussion}

Interpretation in Paul Ricouer's Theory is a kind of dialectic between explanation and comprehension[7]. Explanation is on the level of structural analysis that highlights the objectivity of a work[7][8]. While comperhension is on the level of seeing texts subjectively by referring to the context of what is outside the text. That way, interpretation may come in a form of self-understanding (reflection). And to reach that interpretation, reading metaphors and symbols on "Mêong Palo Karellaê" sureq text should be done since they both are in that area.[9]

Ricoeur[6] explains that first, metaphor analysis moves on two axes, namely (1) from metaphor to text as an explanation representation and (2) from text to metaphor as a representation of interpretation of understanding. Second, the analysis of moving symbols is at (1) the meaning of the symbol as a semantic moment and (2) the meaning of the symbol as a non-semantic moment. "Mêong Palo Karellaê" sureq text is interpreted by using those two steps. Therefore, the meaning of the text can be revealed as a discourse.

\subsection{Metaphor Reading}

When reading metaphors and symbols of sureq text, it s essential to see the context of the content and story. So, the knowledge of "Meong Palo KarellaE" story can serve as a step toward "pre-assumption" to analyze the text.

(1) natunai manaq langi

(2) mupannonno ri tanaê

(3) risoppo ri jênnêq êdê

\author{
'i was defamed by the ruler of sky' \\ 'you dipped me under Earth' \\ 'lifted by water'
}

Metaphor natunai manaq langi ' $\mathrm{i}$ was defamed by the ruler of sky' consists of three words. (1) the word natunai 'defamed' implies about something that is degraded. (2) the word manaq 'me' referred to Mêong Palo Karellaê. (3) the word langi 'sky' represents everything living and coming from a place considered higher, more noble and more powerful over the earth beneath it. Further more, langi 'sky' is a place for the ruler. Therefore, natunai manaq langi is a statement metaphor addressed to disgrace Mêong Palo Karellâe who got punishment from the Ruler of the sky for violating rules. That proves what Ricoeur said that the metaphor of Talking to us about something new, no longer refers to the text, but to reality[10][11].

Metaphor mupannonno ri tanaê 'you dipped me under earth' is another statementmetaphor that consists of mupannonno 'you bring down' as a combination of $m u$ 'you' and pannonno 'bring down'. The combination forms singular identification and universal prediction. The word mupannonno 'you bring down' implies a transformation from a higher 
place to a lower place: something is moved for good purpose. Furthermore, mupannonno 'you bring down' represents two social classes: high and low. Things brought down from a higher place to Earth should be well treated as they must be for the sake of life. The interpretation of the metaphor is that paddy comes from the world above (botinglangi) and is brought down to earth purpose fully for the sake of human's life. So, the seeds should be taken to the rice fields and be planted.

Metaphor risoppo ri jnnêq êdê 'lifted by water' encompasses universal prediction; risoppo 'lifted'. It has no singular proposition, but complementary attribute; ri jênnêq êdê 'by water'. When carefully looked into, the text implicitly refers to Sangiangserri (Godess of Paddy) that in turns occupies the singular proposition that forms statement metaphor. The word risoppo 'lifted' refers to something put on the shoulder and carried away by walking. In a way, the sense of this metaphor reflects a relationship between water and padi. Water plays a big role to the existence of Sangiangserri on earth.

\subsection{Reading the Symbols of Nature}

There are three symbols of nature apearing in every metaphor above; they are sky, earth and water[1][2][12][13][14]. Sky 'botinglangi' in the text reveals position, nobility and power. Sky is above topping the Earth. Due to its position, as a symbol, sky has philosophical meaning representing the upper world, source of divine power that determines the fate and controls the management of life beneath in order to realize the harmony of nature. Natunai manaq langi ' $i$ was defamed by the ruler of sky' is the representation of the power of world in controlling the balance of nature. The word natunai 'defamed' implies a warning of any behavior threatening the balance of nature.

In Buginese cosmology, the world is believed to have three layers; sky 'botinglangi', earth 'ale kawa' and under world 'uriq liu' [2][14][15]. As mentioned earlier, sky is the representation of the upper world. Earth represents the middle world associated with the land where there is life. To agrarian Buginese society, Earth or soil is the source of energy for life so that it must be treated wisely. Mupannonno ri tanae 'you dipped me under earth' reflects the function of land as a place to breed hopes. When paddy seeds are dipped in the ground, new hopes are bred.

That nature comes as the ground for agricultural Bugis to breed hopes is reflected in the discourse of risoppo ri jênnêq êdê 'lifted by water'. The word water here cannot be literally interpreted; it has symbolic meaning. Water supports life on Earth. It has a strong connection to paddy as a source of energy for human. Paddy will only grow well when it is sufficiently watered. Eventhough water is indispensible in life, it may be destructive as well. Therefore, the nature of water can be a reflection for people to learn. What is more important is how to interpret and understand the signals sent by nature in various symbols.

\section{Conclusion}

The face of nature in massureq oral tradition is portrayed in symbols of sky, earth and water which are present in "Mêong Palo Karellae" sureq text with some tendency. Those three symbols speak a lot about local wisdom resulted from nature. They also represent the cosmology of Buginese life. And reading metaphors and symbol by using Paul Ricoeur's hermenetics gives us holistic comprehension of the ideal face of nature to agrarian Buginese society. The standard of ideal face of nature in that context refers to the balance and harmony of elements of nature that are interconnected. 
The balance and harmony of nature in the context of this meaning does not only talk about the environment, but also about humans. In humans, there are feelings and thoughts that need to be in line in order to create harmony for the sake of peace. The form of peace in humans is maintaining good qualities, such as being honest and polite. Therefore, "Mêong Palo Karellae" sureq text implies that humans not only need to maintain the balance of the nature where they are, but also have to maintain balance from within themselves. The face of nature which is depicted through the massureq oral tradition is seen from the attitude of humans in interpreting and organizing their lives wisely.

\section{Acknowledgements}

This article is a small part of the dissertation that the writer is working on under the guidance of the promoter and co promoter. So, the author would like to thank Prof. Dr. Heddy Shri Ahimsa Putra, M.A., M.Phil., As the promoter and Dr. G.R. Lono Lastoro Simatupang, M.A., as a co-promoter, who has helped direct the writer in the process of writing a dissertation at Gadjah Mada University.

\section{References}

[1] A.Sulkarnaen, "Kelanjutan Tradisi Lisan Maddoja Bine dalam Konteks Perubahan Sosial Masyarakat Bugis,” Masy. Indones., vol. 43, no. 2, pp. 261-274, 2017.

[2] N.Rahman, Kearifan Lingkungan Hidup Manusia Bugis. Makassar: La Galigo Press, 2009.

[3] S.Danerek, "Peran Tradisi Lisan dan Komunitas Adat Palue dalam Tradisi Lisan," in Merayakan Keragaman Tradisi sebagai Warisan Budaya, 2014.

[4] D.Wilson D, "A Study on Oral Tradition as a Communication Tool," Int. J. Res. Econ. Soc. Sci., vol. 5, no. 7, pp. 118-124, 2015.

[5] K. Anwar, "Ecological Wisdom of Oral Tradition: Surface and Deep StructureTension in Preserving the Lake Environment," in Earth and Environmental Science, 2020.

[6] P.Ricoeur, Interpretation Theory: Discourse and the Surplus of Meaning. Texas: The Texas Christian University Press, 1976.

[7] P.Ricoeur, Hermeneutics and Human Sciences: Essays, on Language, Action, and Interpretation. Cambridge: Cambridge University Press, 1982.

[8] W.Fithria, "Islam dan Adat Minangkabau dalam Pemikiran Hamka: Perspektif Hermeneutika Paul Ricoeur dan Relevansinya dengan Kemajemukan di Indonesia," Gadjah Mada University, 2013.

[9] H. Kurniawan, Mistisisme Cahaya. Yogyakarya: Grafindo Litera Media, 2011.

[10] P.Ricoeur, Teori Interpretasi. Yogyakarta: Ircisod, 2012.

[11] Ahmad Norma Permata, "Hermeneutika Fenomenologis Paul Ricoeur," in Belajar Hermeneutik: Dari Konfigurasi Filosofis Menuju Praksis Islamic Studies, Yogyakarta, 2012, pp. 242-270.

[12] F.A.Enre, Ritumpanna Welenrennge: Sebuah Episode Sastra Bugis Klasik Galigo. Jakarta: Yayasan Obor Indonesia, 1999.

[13] C. Pelras, Manusia Bugis. Jakarta: Nalar bekerja sama Forum Jakarta_Paris, 2006. 
[14] Mattulada, Latoa. Yogyakarta: Gadjah Mada University Press, 1985.

[15] Ridhwan, "Kepercayaan Masyarakat Bugis Pra-Islam," Ekspose, vol. 17, no. 1, pp. 481-498, 2018. 